\title{
Counterterrorism Policies and Attitudes Towards Out-Groups: Evidence from a Survey Experiment on Citizens' Attitudes Towards Wiretapping
}

\section{Dag Arne Christensen ${ }^{1}\left[\right.$ J Jacob Aars ${ }^{2}$}

Published online: 6 November 2019

(c) The Author(s) 2019

\begin{abstract}
Terrorism often leads to increased stigmatization of groups perceived as "outgroups". We test two versions of out-group theory and ask whether citizens clearly distinguish between radical Muslims and Muslims in general, or if the fear of terrorism is associated with a general distrust of Muslims? We conducted a survey experiment among Norwegian citizens designed to determine the effect of group treatments on the participants' attitudes towards wiretapping. We find that our group treatments strongly influence the participants' attitudes towards wiretapping. However, the hypothesis that the fear of terrorism leads to a backlash against Muslims in general is rejected. Still, Norwegians are prepared to give the police leeway towards the two groups identified by the police as the greatest security risks, i.e., radical Muslim and extreme right-wing groups. Our evidence suggests that citizens are capable of discriminating between groups who aim explicitly at undermining democracy and groups perceived as different from themselves.
\end{abstract}

Keywords Counterterrorist policies · Civil rights · In-group versus out-group · Survey experiment

\section{Introduction}

Fear and intimidation are crucial components characterizing acts of terror (Wilkinson 1992). Terrorism is not only about the physical or material consequences of an attack but also the psychological impact an attack has on a society, which likely

Dag Arne Christensen

dach@norceresearch.no

Jacob Aars

jacob.aars@uib.no

1 NORCE Society, Bergen, Norway

2 Department of Administration and Organization Theory, University of Bergen, Bergen, Norway 
lingers for many years after the attack. Thus, fighting fear can be a crucial component of counterterrorist policies (Christensen and Aars 2017a, b). However, these policies can be affected by citizens' psychological reactions to acts of terror. According to previous US studies, citizens react very differently to terror incidents, and diverging psychological reactions have different political consequences (Huddy et al. 2005; Huddy and Feldman 2011). Anger and the fear of terrorism have been associated with support for repressive measures, increased intolerance and prejudices against groups and minorities in society. For example, in January 2017, the newly elected US president, Donald Trump, signed an order restricting entry into the country for citizens from seven predominantly Muslim countries. The travel ban targeted a distinct group of people, i.e., Muslims, and limited their freedom of movement regardless of whether they posed a threat. Hence, in the face of a terrorist threat, do people project their fear onto collective groups, such as Muslims in general?

The article makes several contributions to research on the relationship between terrorism and attitudes towards out-groups. First, our research redirects attention away from general attitudes towards out-groups to the civil rights of these groups. To our knowledge, our article is the first to study how the threat of terrorism influences citizens' attitudes towards counterterrorist policies that target specific groups. Second, by distinguishing theoretically and empirically between different types of out-groups, we develop a more nuanced framework for analysing the interplay between out-group characteristics and civil rights. Finally, our study breaks new empirical ground by looking beyond the United States - the most thoroughly studied case when it comes to terrorism and out-group attitudes. We believe that our results suggest further tests on the European side of the Atlantic would be useful. Norway represents a tough case because it is a high-trust country. In addition, Norway has recently experienced right-wing terrorism. The terrorist attack was met by a resounding rejection and a rally around common values.

Since the 9/11 attacks in the United States, anti-terror policies have been on political agendas in all countries in the Western World. Although the Norwegian experience with terrorism was fundamentally altered after the 7/22 terrorist attacks at Oslo and Utøya, the country has been spared from such terrifying incidents (Fimreite et al. 2013; Nordenhaug and Engene 2008). The 9/11 attacks in the US were conducted by a group of radical Muslims who acted on behalf of a wider terrorist network. In Norway, the 7/22 attacks were conducted by the right-wing extremist Anders Breivik acting on behalf of no one but himself. Terrorist attacks create an immediate state of emergency and, in the long term, represent important crossroads in the transnational fight against terror (Bloch-Elkon 2011; Epifanio 2011). Since $9 / 11$, the fear of terrorist attacks has moved political leaders in many countries to curtail civil rights (Epifanio 2011; Mueller and Stewart 2012; Engene 2013, 2016; Lehrke and Schomaker 2014; Pokalova 2015). However, countries strongly differ in their response to terrorism. According to Epifanio (2011, p. 399), certain countries (for instance, the U.S. and UK) have "implemented the full battery of regulatory responses while others (i.e., Scandinavian countries and Switzerland) remain reluctant to cut deeply into the net of civil rights for citizens, suspects and immigrants alike". In 2015, over one million refugees entered Europe from embattled 
countries, and the increased number of refugees has further shifted the focus in the fight against terrorism (Roth 2016). The combination of the fear of terror and the increased number of refugees has contributed to increased support for extreme right-wing parties, candidates and groups (Inglehart and Norris 2016). Thus, terrorist threats place democratic regimes under severe pressure. Although actual attacks rarely occur in most countries, the threat posed by terrorism can create fear among citizens. Western Europe experienced a sharp increase in terrorist incidents in 2015, and 2016 when several attacks were conducted by the Islamic State of Iraq and the Levant (ISIL). Even if the fears are exaggerated, fearful responses to terrorist threats may induce governments to act decisively. In turn, decisive action to counter terrorism and protect citizens often implies a weakening of certain basic democratic rights of citizens, specific minorities, and values that underpin democratic government. Hence, in their efforts to protect the democratic government, the decision-makers run the risk of undermining the basics of democracy.

This article presents the results of a survey experiment developed and executed to determine whether Norwegian citizens' attitudes towards wiretapping are conditional on the group(s) targeted. Specifically, we examined whether attitudes towards wiretapping conducted by the Police Security Service (PST) are dependent on the social groups wiretapped by the PST. In this study, a realistic terrorist scenario is established, and the name of the social group to be wiretapped is randomized. We focus on the use of wiretapping as a well-known counterterrorism method in the fight against terrorism. The use of such methods is justified because these methods can contribute to the prevention and detection of various criminal actions with potential dramatic consequences for society. The argument against these methods is that they may violate basic democratic rights, such as the rule of law and privacy.

Our study has two specific aims. First, based on group-categorization theory, we aim to determine whether citizens are guided by their principles regarding wiretapping or whether they allow the PST greater leeway to wiretap certain social groups. Which groups represent the largest threat according to the citizens? Do citizens differentiate between radical Muslims (out-group) and Muslims in general (in-group) or is there a general stigmatization of Muslims in the population overall? Second, citizens could react differently to the group treatments because of their different ideological predispositions. In the analysis, we test whether the treatments interact with support for the right-wing anti-immigrant Progress Party (PP).

This study reveals that exposing citizens to different social groups strongly influences their attitudes towards wiretapping. Norwegians are willing to provide leeway to the PST in investigating the two groups identified by the PST as the greatest potential security risk, i.e., radical Muslim and extreme right-wing groups. Both groups are out-groups that have shown the willingness to cross the boundary of what is acceptable in a democracy. However, our respondents clearly distinguish radical Muslims from Muslims in general. Citizens are not more willing to support the wiretapping of a Muslim congregation than the respondents in the control condition (a social group). These findings highlight the importance of distinguishing between the two versions of out-group theory, the first focusing on groups that demonstrably pose a terrorist threat and the second focusing on peoples' general perceptions of groups in society. Furthermore, overall support for wiretapping is higher among 
Progress Party supporters than among supporters of other parties. PP supporters exposed to the Muslim congregation treatment are not significantly more likely to support wiretapping than PP supporters in the control group.

First, we briefly review the context of our study. Based on this overview and group-categorization theory, we outline the expectations of our findings. Then, we describe the data and our experimental design. Finally, we present the results and discuss the policy implications of our findings.

\section{The Context of the Study}

Although Norway has been reluctant to deeply reduce the civil rights of certain citizens, such as suspects and immigrants, the police have been given greater discretion over time (Husabø 2013; Engene 2016). In 2005, the police were granted the opportunity to use wiretapping in conjunction with extended forms of crime, and the ban on covert audio surveillance was lifted. Previously, the PST (the police) needed reasonable ground to engage in hidden surveillance, but currently, no special permission is needed to use these methods (Husabø 2013). In May 2016, the Norwegian parliament passed a bill allowing the PST to tap phones and conduct surveillance of other types of communication, such as e-mails and computer traffic (so-called "computer reading") if a possible terrorist plot is suspected (Innst. 343 L (2015-2016)). These methods may weaken the individual rights and privacy of individuals and groups in society.

The policy responses of established democracies to the threat of terrorism are controversial. Certain scholars consider these policies necessary, while other scholars believe that these measures are too extreme (Chenoweth 2013; Engene 2016). The debate involves not only the need for stricter counterterrorist measures (Sunstein 2004; Mueller and Stewart 2012) but also the policy tools that are implemented. There is no consensus regarding which policies are most effective in fighting terror (Mueller and Stewart 2012; Dragu and Polborn 2014; Neumayer et al. 2014; Engene 2016). Thus far, the objectives have been to expose potential terrorists and eliminate their organizations. According to the critics, there has been less focus on prevention and the fight against violent extremism as the means to prevent the recruitment of individuals to terrorist organizations. Whether the politicians' focus on the "supplyside" has led to more security is uncertain (Sunstein 2004). According to Dragu and Polborn (2014, p. 513), "researchers have yet to determine whether enlarging executive discretion at the expense of fundamental rights liberties increases security from terrorism, even though all prominent (liberty-reducing) counterterrorism policies assume it does". According to these researchers, a repressive anti-terror policy could have substantial costs by undermining the legitimacy of the political system among groups in which potential terror groups have their roots. These policies could lead to group stigmatization and thus more, rather than less, terrorism.

How societies can best protect themselves from terrorism has become an important political dividing line in Western democracies (Pantazis and Pemberton 2009; Engene 2016). The key question in this debate is how societies find a balance between civil rights and the need for safety. How this discussion is framed 
has changed (Davis and Silver 2004). Before 2001, the debate had a stronger focus on citizens' need for protection against the authorities (the state). After $9 / 11$, the focus has shifted to how limits need to be pushed in the fight against a common external enemy (the terrorists). The latter frame expands the number of possible political solutions. For instance, the former president of France, Nicolas Sarkozy, has proposed integration camps or electronic tagging of terror-suspected Islamists regardless of whether they have actually committed a crime (The Economist September 3 2016). These types of proposals occur in light of the new security context after 9/11. Opinion studies have shown that citizens' attitudes are contingent on how political questions are framed (Berinsky 2016; Druckman and Lupia 2016). Threatening events and a common external enemy can lead the population to support policies that weaken the legal safeguards of certain social groups in the population. Terrorism creates the impression that the authorities do not have the necessary control (Altheide 2006; Lerner et al. 2003), and citizens might be willing to support far-reaching policies to avoid fear, particularly in regard to groups that differ from themselves (Sunstein 2004).

Our main research question concerns whether the degree of support for stricter counterterrorism measures is conditioned on the groups such measures are targeting. Therefore, in the following discussion the centre of attention is groupcategorization theory.

\section{Group-Categorization Theory and Expectations}

Do citizens consider civil and political rights absolute or do opinions on wiretapping depend on the group targeted by the counterterrorist police authorities? Will citizens clearly differentiate between a random group in society and Muslims in general? Do attitudes towards members of perceived deviant groups vary according to the respondents' ideological predispositions? These questions serve as a foundation for the subsequent discussion and analysis.

The overall question is whether civil rights are perceived as absolute or whether the population conducts a more pragmatic assessment regarding the question of surveillance (Beetham 1999). Rights are considered absolute if they cannot be ignored under any circumstances regardless of the consequences (Gewirth 1981, p. 2). Thus, rights are unconditional. If citizens consider rights absolute, their attitudes should not be affected by the groups under surveillance. This position represents the following null hypothesis in our analysis:

$\mathbf{H}_{0}$ Citizens' attitudes towards wiretapping are unaffected by the group wiretapped by the police authorities.

However, numerous studies argue that citizens associate the principles of privacy and the rule of the law with various social groups (Chong 1993). People simplify the subject by sorting individuals into groups when making concrete 
assessments (Petersen et al. 2011). Two versions of the so-called "group-categorization" theory guide our experiment.

The first version focuses on the characteristics of the groups. According to this version, citizens are more willing to restrict the freedom of speech of groups who actively proclaim their preparedness to violate the democratic fabric of society (Sniderman et al. 2014). Citizens are expected to relate political rights to subgroups expressing views that conflict with those of the broader society or groups that operate on the edge of the law or the perceived common moral norms of society. Thus, citizens' attitudes towards counterterrorist measures can be based on information about groups that might represent a threat to their safety. Anti-terrorist measures focus on the same types of out-groups in society. In their risk analysis, the PST has identified radical Muslim groups and right-wing extremists as the most important risk groups (PST 2016), which is unsurprising considering the international terror events and Norwegian experience with terrorism in 2011. The PST assesses radical Islam as the greatest threat, but the threat from right-wing extremists is considered to be increasing (PST 2016, p. 2). The PST considers the increasing threat from the extreme right in light of "mobilization around issues related to refugees and asylum seekers". The two forms of extremism in the PST risk reports, i.e., radical Islamism and extreme right extremism, are examples of out-groups. Both out-groups have demonstrated that they are willing to cross the boundary of what is deemed democratically acceptable, and therefore, we expect citizens to give the PST permission to follow these two groups closely. Thus, we approach our empirical analysis with the following hypothesis:

$\mathbf{H}_{1}$ Citizens are more likely to support wiretapping if the wiretap targets a radical Muslim group or a right-wing extremist group.

The second version of the group-categorization theory is based on the рориlation's perceptions of different groups rather than on the group characteristics. Studies that have been conducted in the American context indicate that the fear of terrorism strengthens group identity towards in-groups, while at the same time the population becomes increasingly hostile towards groups perceived as "different" (Sunstein 2004; Huddy et al. 2002, 2005; Das et al. 2009; Huddy and Feldman 2011). The combination of frightening terrorism events and immigration can lead citizens to become increasingly fearful, angry and concerned about security in a society characterized by greater ethnic diversity. For instance, the concept of "securitization" implies that the issue of security has such a strong salience that it is incorporated into most other policy areas and thereby legitimizes heavyhanded measures to regain security (Buzan and Wæver 2003, p. 491). In such a heated atmosphere, the issue of immigration could transmute into a question of security, and all immigrant groups risk could be portrayed as security threats. Hence, do people clearly differentiate between radical Muslims and Muslims in general or do they view all Muslims as belonging to the same category? Previous studies have shown that negative perceptions of Muslims are widespread in Europe (Strabac and Listhaug 2008; Savelkoul et al. 2012; Ogan et al. 2014). Do 
these anti-Muslim attitudes increase citizens' willingness to accept greater intervention against Muslims in general? According to a study investigating Norwegians' attitudes towards Muslims using open questions, many Norwegians consider Muslims a threat to important societal values, and formulations related to terrorism are not uncommon (Moe et al. 2016, p. 9). Does a perceived security threat increase the willingness to permit greater leeway for the PST to wiretap Muslims in general? Muslim communities are likely considered recruitment venues for future terrorists, and a general stereotypical perception of Muslims as a group exists. Therefore, in our experiment, we tested whether citizens distinguish between radical Muslims and Muslims in general when confronted with a realistic terror plot. Norway should be a strong test of backlash against Muslims in general. Norway is one of the highest-ranking trust countries (Wollebæk et al. 2012), something that could provide democratic resilience towards stigmatization of out-groups. Another difference is Norway's experience with right-wing extremist terrorism that brought citizens together rather than drove them apart. A natural experiment studying attitudes towards immigrants around the 2011 terror attacks finds that Norwegians became more positive towards immigrants after the attacks (Jakobsson and Blom 2014). The analysis tests the following hypothesis:

$\mathbf{H}_{2}$ Citizens are more likely to support the wiretapping of a Muslim congregation than the wiretapping of a random social group.

In addition, we assume that the respondents will react differently to identical stimuli because people have different predispositions. In addition to the two versions of the group-categorization theory, we predict distinct differences in citizens' attitudes towards wiretapping depending on their political preferences. Because people cannot monitor every issue, they rely on party preferences as shortcuts in forming their opinions (Tilly and Hobolt 2011). Numerous studies have shown that partisanship acts as a filter to enable citizens to understand policies, particularly following dramatic events (Gadarian 2010; Klar 2013; Albertson and Gadarian 2015). According to studies performed in the U.S., ideological cues have implications for political attitudes, particularly towards out-groups (Zavala et al. 2010; Hatemi et al. 2013). For instance, right-wing party identification is associated with stronger anti-immigrant attitudes and prejudicial attitudes towards members of stigmatized groups. We examined these heterogeneous effects using support for the Progress Party (PP). The PP is frequently characterized as a somewhat marginal case of a radical right-wing party. For instance, Mudde (2016, p. 2) labels the PP a "neo-liberal populist" party. However, an essential issue for the PP is to limit immigration, particularly from non-Western and Muslim countries, and anti-immigrant attitudes are widespread among PP supporters (Berntzen and Sandberg 2014). The PP also warns against the Islamization of Norwegian society, and the PP's chairwoman, Siv Jensen, introduced the term "stealth Islamization" (snik-islamisering) in her speech to the party's congress in 2009 (Bangstad 2013). Therefore, by performing an empirical analysis, we examine whether PP supporters are more inclined to support the wiretapping of Muslims in general. 
$\mathrm{H}_{3}$ PP supporters are more inclined to support the wiretapping of a Muslim congregation than the wiretapping of a random social group.

To reveal possible hidden preferences and provide robust evidence regarding the importance of group cues in citizens' attitudes towards wiretapping, we conducted a survey experiment. In the following section, we describe the data and experimental design.

\section{Data and Experimental Design}

The data are derived from the Norwegian Citizen Panel, which is an Internet-based survey about Norwegians' attitudes towards different topics in society. The panel is operated by social scientists at the University of Bergen and NORCE (Norwegian Research Centre) and is used for research purposes only. The panel is not selfrecruiting, and thus, the participants represent a cross section of the Norwegian population. The panel participants are invited to provide their opinion twice a year.

We collected our data between October 28 and the middle of November of $2015{ }^{1}$ The data were obtained from a random sample of 1500 respondents from a total of 10,247 panel members (Skjervheim and Høgestøl 2015). To reveal whether people relate political rights and tolerance to specific social groups, we designed our study as a survey experiment (Mutz 2011). The alternative would have been to ask the respondents direct questions regarding the social groups that they would allow the PST to wiretap. The experimental design of the survey has several advantages for understanding how citizens form their opinions. First, people's attitudes towards the wiretapping of specific social groups represent a sensitive topic, and respondents may not disclose their actual attitudes when asked direct questions about this topic (Rosenfeld et al. 2016). Thus, using direct questions might result in the underreporting of the respondents' willingness to permit the PST to wiretap certain groups. For example, we could not be able to reveal peoples' attitudes towards Muslims in general. Second, the random allocation of treatments ensures that the potential attitudes of the individuals in the treatment groups are identical to the potential attitudes of those in the control group. Hence, this method is highly useful for shedding light on the causes of attitudes (Cappelen et al. 2016).

We designed a straightforward experiment. The survey respondents were presented with a potential realistic terror plot. We only manipulated one variable, i.e., the social group to be wiretapped by the PST, and all other conditions remained constant. Hence, in this experiment, we could test whether exposure to distinct social groups shapes the respondents' attitudes towards wiretapping. In total, 1500 randomly selected respondents were asked the following question:

\footnotetext{
1 The data were collected only days before the terror attack in Paris on November 13, 2015. Approximately 50 answers were registered the day after the attack; thus, we cannot determine the impact of the event.
} 
Imagine that the Police Security Service (PST) has requested permission to wiretap the phones of members or sympathizers of [group $\mathbf{X}$ ] because they believe it might help them investigate a terror plot. Some people agree that the PST should be allowed because it may avert terror plots early, while others believe that the PST should not be allowed because it would be an excessive interference with the privacy of the group. Do you agree or disagree that the PST should be allowed to perform such wiretapping?

The question referred directly to the investigation of a terror plot, with an accompanying request by the PST to use wiretapping to avert the terror plot. Our intention was to create an experiment that was as realistic as possible, and wiretapping was selected as a covert police method because most people are likely familiar with this method. Then, we randomly assigned the individuals to one of five groups: a control group and the following four different treatment groups:

(1) "A radical Muslim group"

(2) "A Muslim congregation"

(3) "A right-wing extreme group"

(4) "The Progress Party (Fremskrittspartiet)"

(5) "A social group" (Control group)

The first four groups constituted the treatment groups, while the respondents exposed to a "social group" constituted the control group. In designing survey experiments, reflecting upon the requirements of a good control group is necessary. Using a neutral category as the control group is a well-known and recommended solution (Alebertson and Gadarian 2016, p. 485). The term "a social group" meets this requirement and is neutral both in religious and political terms. We assume that the respondents associate a social group with any grouping in society. The question had seven response categories ranging from "strongly agree" (1) to "strongly disagree" (7). The experiment randomly exposed the respondents to two extreme social groups on two dimensions. The first dimension was the "Muslim" dimension, i.e., "a Radical Muslim group" (out-group) versus "a Muslim congregation" (in-group). The second dimension was the "right-wing" dimension, i.e., "a right-wing extremist group" (out-group) versus the "Progress Party (PP)" (in-group). Although we had no reason to believe that citizens would support the wiretapping of the members and sympathizers of the PP, this party was selected as a contrast to the extreme rightwing groups. ${ }^{2}$

Because 1500 respondents participated in this study, a maximum of 300 respondents could be randomly assigned to each of the five groups. The final analysis included 1399 respondents. The number of missing values is equally distributed

\footnotetext{
2 The Progress Party was the only group specified in the experiment. We considered naming (specifying) groups on the other dimensions as well, but we feared that doing so would result in a larger proportion of missing answers since we expected these groups to be less known among the public. In addition, the PST use the more general concepts (right-wing extremists, and radical Muslims) in their risk assessments.
} 


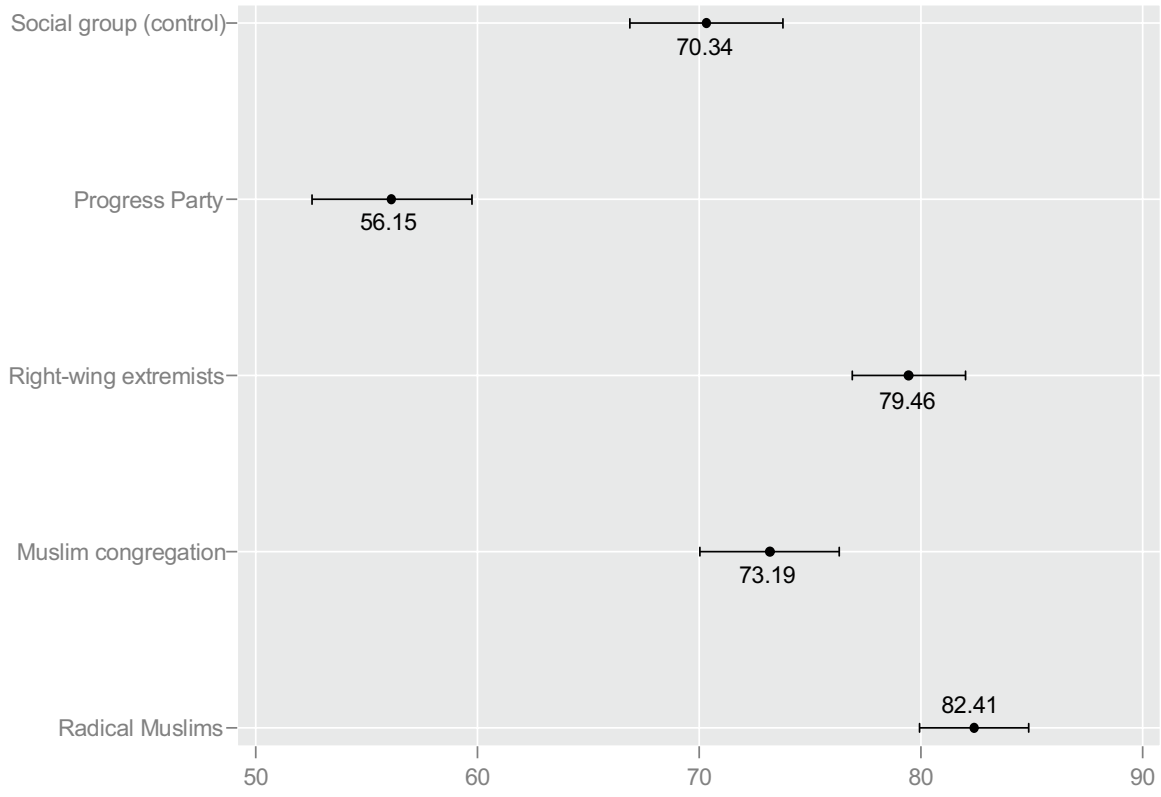

Fig. 1 Attitudes towards wiretapping: Group-categorization experiment (Averages with 95\% CI's$\mathrm{N}=1399$, scale 0 (strongly disagree) to 100 (strongly agree)

across the five groups, and therefore, we assume that the number of missing values is random. The results of the multinomial regressions using the control group as the base outcome verify that the treatment groups were balanced in terms of gender, age, education and partisanship (see Table 3 in the appendix). None of these background characteristics approached the conventional levels of statistical significance ( $\mathrm{p}<0.05$, two tailed). Compared with the control group, the university educated respondents and female subjects had a slightly higher probability of being assigned to the right-wing extremist group ( $p<0.10$, two tailed). To enhance clarity, we changed and standardized the scale in the final empirical analysis such that 100 represents "strongly agree" and 0 represents "strongly disagree".

\section{Results}

The empirical analysis was performed in three steps. First, we performed a simple bivariate regression analysis to compare the four treatment groups to the control group. Second, we tested the groups against each other in pairs. Third, we tested whether the treatments interact with support for the Progress Party.

Did the respondents identify the two extreme groups in the experiment? Does the fear of radical Muslim groups influence peoples' attitudes towards Muslims in general? We performed a simple comparison of the average attitudes towards wiretapping between the control and treatment conditions. 
These numbers are provided in Fig. 1. First, we consider the overall level of support for wiretapping. The results indicate that Norwegians are highly willing to permit the PST to wiretap people's phones to prevent terrorist attacks. Hence, people's trust in the PST appears to be high. Across all groups, the average is 72.3 on the scale ranging from 0 to $100(0=$ strongly disagree and $100=$ strongly agree $)$. Notable, the question clearly states that the PST actually considers wiretapping as helpful in an investigation of a potential terrorist plot. In addition, previous studies have shown that compared to other measures, such as holding people in detention without a trial, wiretapping as a counterterrorist measure is widely supported within the population (Fimreite et al. 2013). In this study, the respondents' trust in the PST was relatively high. However, this finding also indicates that people do not consider privacy an absolute right. If wiretapping was considered a serious infringement of privacy rights, the respondents would likely be less willing to permit the PST to interfere with other people's personal lives.

Second, our study provides strong evidence against the null hypothesis that citizens' attitudes are unaffected by the group to be wiretapped by the PST. Privacy rights are not considered absolute and are highly dependent on the targeted group. The average level of support for wiretapping under the control condition (a social group) is 70.34, and unsurprisingly, people are least willing to use wiretapping against members of the PP (average $=56.15$ ). The PP is an established party in the Norwegian system and is one of the two current member parties in the Norwegian coalition government. The underlying reason of these differences is unclear, but this result could indicate that the surveillance of political parties is a sensitive topic. Also, the PP is the only group that is specified directly in the experiment. Furthermore, as we expected, the request by the PST to wiretap the two extremist groups was supported by the respondents. The average level of support for the wiretapping of right-wing extremists is 79.45 while the corresponding number for the wiretapping of a radical Muslim group is 82.41. Both figures are significantly higher than that in the control group, thus providing support for our first hypothesis. Furthermore, the Norwegians clearly distinguished between radical Muslims and Muslims in general ("a Muslim congregation"). The average of the respondents exposed to "a Muslim congregation" is 73.19, while the corresponding number in the control group is 70.34. As indicated by the overlapping confidence intervals between these two groups, the difference is not significant. Hence, the analysis rejects our second hypothesis, which posits that faced with a terrorist threat citizens stigmatize Muslims in general. The citizens' support for wiretapping Muslims appear to be as strong as for wiretapping any other group in society. However, we cannot exclude the possibility that respondents in the control group might have thought about Muslims as a potential social group to wiretap. Furthermore, we conducted the experiment prior to many of the recent major terrorist attacks in Europe, such as the Paris attacks in November 2015 (130 people killed), the bombs in Brussels in March 2016 (32 people killed), and the attack in Nice in July 2016 (84 people killed) (Nesser 2014; Nesser et al. 2016; Europol 2016).

These initial results have three important implications. First, our treatments had considerable effects on the citizens' attitudes towards wiretapping. Second, the exposure to the two extremist group cues significantly increased support for wiretapping. 
Table 1 Wiretapping: test of pairwise group differences (scale $0-100, \mathrm{~N}=1399$ )

\begin{tabular}{lc}
\hline Groups & Difference (standard errors) \\
\hline Muslim congregation vs. Radical Muslims & $-9.23(2.030)^{* * *}$ \\
Right-wing extremists vs. Radical Muslims & $-2.95(1.804)$ \\
Progress Party vs. Radical Muslims & $-26.26(2.229)^{* * *}$ \\
Social group (control) vs. Radical Muslims & $-12.07(2.163)^{* * *}$ \\
Right-wing extremists vs. Muslim congregation & $6.28(2.058)^{* *}$ \\
Progress Party vs. Muslim congregation & $-17.04(2.439)^{* * *}$ \\
Social group (control) vs. Muslim congregation & $-2.85(2.379)$ \\
Progress Party vs. right-wing extremists & $-23.31(2.255)^{* * *}$ \\
Social group (control) vs. right-wing extremists & $-9.12(2.189)^{* * *}$ \\
Social group (control) vs. progress party & $14.19(2.551)^{* * *}$ \\
\hline
\end{tabular}

$* * 5 \%$-level, $* * * 1 \%$-level

Third, no difference was observed between the Muslim congregation treatment and the control condition. Norwegians do not consider civil rights absolute and make pragmatic assessments according to the group the PST intends to monitor.

Figure 1 illustrates the average level of support for wiretapping in the four treatment groups against the control condition ("a social group"). Next, we present the results of the analysis in which each pair of groups was tested against each other. The results are shown in Table 1. Two findings are particularly interesting. First, as shown in Fig. 1, the respondents clearly distinguished between Muslims in general and radical Muslims. Norwegians are far less likely to accept a request from the PST to wiretap members of a Muslim congregation than to accept the wiretapping of a radical Muslim group. The difference is $-9.23 \%$ points and is significant. This result is consistent with an experimental study performed in Denmark after the so-called cartoon controversy in 2005 and 2006 (Sniderman et al. 2014). Furthermore, this result is consistent with findings from Norwegian studies investigating the restriction of the freedom of expression in various social groups, including Muslims (Midtbøen and Steen-Johnsen 2016; Steen-Johnsen et al. 2016). Second, the respondents are not less likely to accept a request from the police to wiretap a radical Muslim group compared to a request to wiretap a right-wing extremist group. The difference between the two groups is small $(-2.95)$ and does not achieve the conventional $5 \%$ level of statistical significance $(\mathrm{p}<0.10$, two tailed). Thus, the respondents appear to consider the two groups as equally important threats. This result likely reflects the experience of the attack of 7/22 2011. The perpetrator, Anders Behring Breivik, had the following clear political motivation for the killings at Oslo and Utøya: opposition to immigration in general and the Islamic civilization in particular. The extreme right has not only been a threat in Norway but also a threat that Norwegian citizens have painfully experienced.

Table 1 shows that the citizens are far less willing to accept the wiretapping of members of the PP than the wiretapping of members of a Muslim congregation. The difference is $-17 \%$ points and clearly significant. As previously mentioned, this finding likely indicates that Norwegians are more sensitive to the surveillance of 
Table 2 Wiretapping: test of interaction-effects (ANOVA model with F-statistics, $\mathrm{N}=1399$ )

\begin{tabular}{ll}
\hline & Progress Party model \\
\hline Group-categorization & $16.42 * * *$ \\
Progress party & $21.63 * * *$ \\
Group-categorization $\times$ Progress Party & $2.68 * *$ \\
\hline$* * 5 \%$-level, $* * * 1 \%$-level &
\end{tabular}

political parties in general and the PP in particular. Furthermore, as illustrated in the table, the respondents clearly distinguished between the PP and more extreme rightwing groups.

Finally, we tested whether the treatment effect differed based on political predispositions. Because regressing attitudes towards wiretapping included an interaction term that could lead to conflicting estimates of the main effects, we performed a one-way ANOVA model and graphed the marginal effects (see Mitchell 2012, p. 241). The model includes the treatment groups, Progress Party support and the interactions between the two as explanatory variables. Thus, the treatment interacts with a dummy variable separating the PP supporters from the remaining respondents. Table 2 presents the results of the ANOVA model. The F-statistics reveal that the interaction between treatment and support for the PP is significant at the 5\% level. Therefore, the null hypothesis positing that the average level of support for wiretapping is equal regardless of the treatment to which the PP supporters were exposed can be rejected.

Because the ANOVA only tests whether the interaction is significant, we computed the adjusted average attitudes towards wiretapping by treatment and PP support using the margins (and contrast) commands in Stata. These numbers are provided in Fig. 2. The figure displays that the overall support for wiretapping is higher among the PP party supporters than that among those voting for other parties (and non-voters). The differences are sizeable for PP supporters exposed to the different treatments. The average level of support for wiretapping among the PP supporters in the control group (exposed to a social group) is as high as 84.1, while the corresponding number for the other party supporters is 69.1 (difference $=15 \%$ points). Security therefore has a distinct political dimension. Terrorist attacks place questions of law and order on the political agenda, which are issues strongly associated with right wing conservative ideology (Klar 2013). Thus, concerns of a potential terrorist threat draw a clear line between right and left wing parties included in our reference group. When we compare the PP supporters in the different treatment groups, the PP voters exposed to a Muslim congregation scored around $10 \%$ points higher than the PP voters in the control group. Thus, the PP supporters appeared to be more likely to support the wiretapping of Muslims than that of any other group in society. Even if the effect is substantial, it is not significant ( $\mathrm{SE}=7.39 \%$ points, $\mathrm{p}=0.178$ ). Hence, we can reject our third hypothesis, which posits that PP supporters are particularly prone to support wiretapping if the group targeted was a Muslim congregation. However, future studies are needed to follow up on the impact of ideology. By comparing the PP supporters in the control group with the PP supporters 


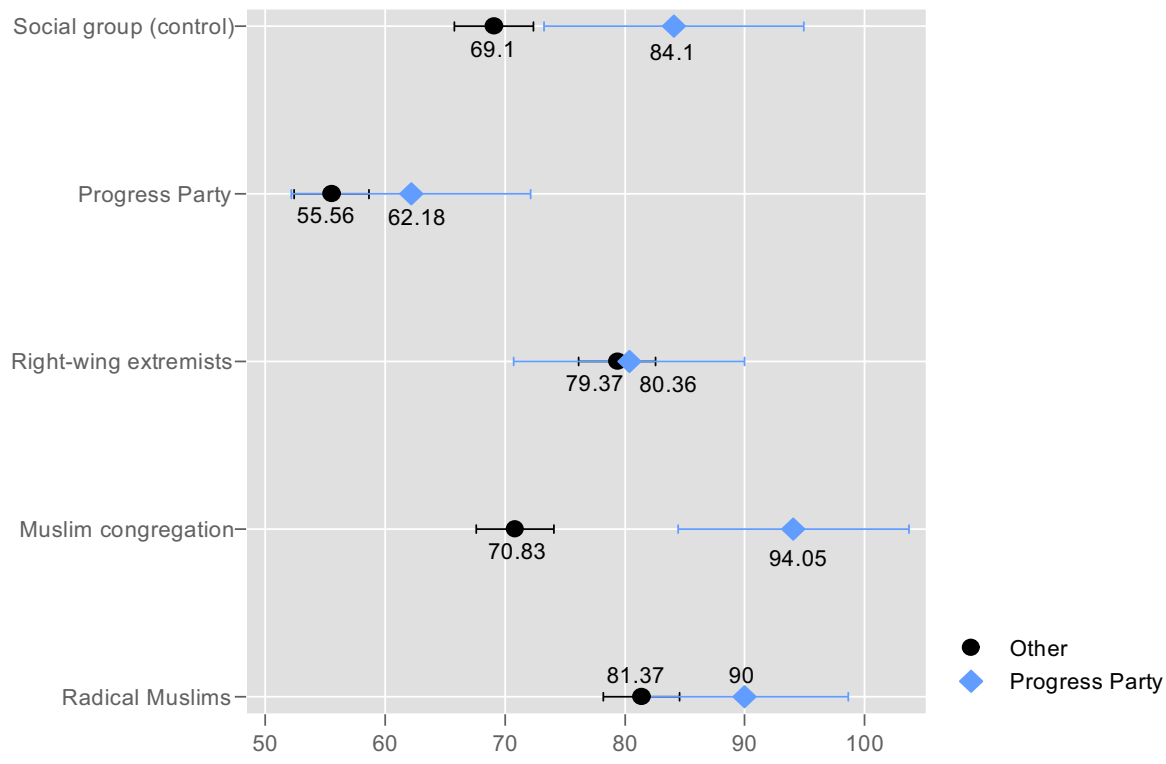

Fig. 2 Wiretapping: Group-categorization interacted with Progress Party support. (Averages with 95\% CI's- $\mathrm{N}=1399$, scale 0 (strongly disagree) to 100 (strongly agree))

in the treatment groups, only the average level of support among the PP voters to wiretap their own party significantly differed. The PP supporters exposed to the PP treatment scored $21.9 \%$ points lower than the PP supporters in the control group $(\mathrm{SE}=7.51 \%$ points, $\mathrm{p}<0.01)$. The PP supporters are, however, more willing to support the wiretapping of their own party than non-PP voters, which highlights the high level of support for wiretapping among the party's supporters in general.

\section{Discussion}

The purpose of this study was to examine how citizens respond to counterterrorist measures confronted with a realistic terrorist threat. We investigated whether attitudes towards wiretapping are conditional depending on the target of the wiretapping. After the attacks in the US in September 2001, citizens' desires to live in safe societies have led to wider acceptance of limiting privacy and, therefore, personal freedom. There is an ongoing debate regarding how far democracies can go in fighting terrorism before democracy itself is undermined. Our analysis contributes to this discussion by addressing the following two questions: (1) Do people's perceptions of wiretapping depend on the target of these measures? (2) Do attitudes towards wiretapping certain groups interact with party preferences? To determine the effect of group cues, we conducted a survey experiment.

The empirical analysis resulted in four conclusions. First, citizens appear to have a high degree of trust in the police's risk assessments. Notably, our experiment directly stated that the PST consider that a wiretap would help them avert a terrorist 
plot. Therefore, the results cannot be interpreted as a carte blanche for surveillance under any circumstances. Moreover, among those exposed to the Progress Party as the target group, we observe a lower willingness to accept wiretapping. This finding may indicate that the population is concerned with the monitoring of political parties in general. Another interpretation is that the support of monitoring decreases as the target group of the wiretapping is more concrete, but this is uncertain. For example, there is no reason to assume that support for wiretapping fundamentalist groups would be reduced if we had identified such specific groups in the experiment. Advance knowledge may also play a role in attitudes towards wiretapping. For example, a reference to a concrete group (such as the PP) allows the respondents to critically assess the need for monitoring.

Second, exposing citizens to different social groups is highly important for determining how people form opinions regarding counterterrorist measures. Therefore, this study provides strong evidence against the hypothesis that the rights of individuals are considered absolute. The attitudes strongly depended on the intended target group of the potential wiretap. The population was most prepared to permit the PST to investigate the two groups that the PST identified as the greatest potential security risks, i.e., radical Muslim and extreme right groups. Both groups are classic outgroups that have previously demonstrated that they are willing to cross the borders of what is acceptable in a democracy.

Third, the respondents appear to clearly differentiate between radical Muslims and Muslims in general. Norwegians are not more inclined to support the wiretapping of a Muslim congregation than the wiretapping of any other group in society. Thus, the fear of terrorism is not associated with a backlash against Muslims in general. After the terrorist attacks in Norway in 2011, Norwegian politicians reacted by encouraging the population to display solidarity and fellowship. The words and actions of politicians (and the media) in response to terrorist incidents may affect citizens' attitudes (Sniderman et al. 2019). However, we conducted our study before many of the major and deadly terrorist attacks in Europe. Many of the terrorist attacks in Western Europe in the past few years have had certain links to extreme Islamists and, therefore, might have had an impact on the attitudes towards the use of covert police methods.

Fourth, respondents react differently to the different treatments because of different political predispositions. Respondents supporting the Progress Party (PP) are more inclined to support wiretapping regardless of the targeted group compared to the respondents supporting other parties. PP supporters are even more willing to support the wiretapping of their own party compared to non-PP voters. PP supporters are also more inclined to support the wiretapping of Muslims, but even if the effect is substantial, it is indistinguishable from zero compared to PP voters in the control condition.

The results of our study should inspire future survey experiments to follow the same respondents over time to reveal how stable or context dependent these attitudes are. Future group-categorization experiments may also add to the literature by studying attitudes both across countries and across different counterterrorist measures such as holding people in detention without a trial and surveillance of e-mails and computer traffic. 
Overall, do the results of this study indicate that people do not perceive privacy as an absolute right? In general, the respondents significantly supported permitting counterterrorist police authorities to use hidden surveillance methods if there is a terrorist threat. Norwegians' high level of trust in police authorities may also turn out to be a double-edged sword, which may in turn make it easier to convince citizens to accept extreme measures. Furthermore, this approval is conditional upon the group the surveillance is supposed to target. Hence, the results could be understood in light of the theory of so-called "out-groups". However, only one version of the "out-group" theories is supported in our study. The respondents in this survey are most open to wiretapping if the target groups demonstrably have posed a terrorist threat. In essence, the population supports the threat assessments of the counterterrorist police. Muslims in general are not perceived as a terrorist threat.

Policy makers in Norway and elsewhere have met the terrorist threats by granting the counterterrorist authorities increased opportunities to use secret police methods (e.g. wiretapping and data-sampling) in the fight against terror. Our survey helps shed light on the public support for strict counterterrorist measures. This study reveals that the subjects of such methods directly affect the citizens' attitudes. The citizens' support of restrictive counterterrorist measures likely depends on how the balance between privacy and the rule of law and safety is interpreted. Before the attack in the US in 2001, the discussion revolved around how citizens could be protected from the state; however, the current debate is focused on how citizens and the state need to protect themselves against a common enemy (terrorists). Therefore, support among citizens towards the use of hidden police methods highly depends on how the fight against terrorism is framed. Further work is needed in the European arena to see how such frames impact citizens' group specific attitudes.

Acknowledgements We are grateful to NordForsk (Grant Number 88043) who funded the research project on which this article is based. We also thank the anonymous reviewers and the editor for their constructive comments. Data and code to replicate our results is available at https://dataverse.harvard.edu/ dataset.xhtml?persistentId=doi:10.7910/DVN/RUNY3Y.

Open Access This article is distributed under the terms of the Creative Commons Attribution 4.0 International License (http://creativecommons.org/licenses/by/4.0/), which permits unrestricted use, distribution, and reproduction in any medium, provided you give appropriate credit to the original author(s) and the source, provide a link to the Creative Commons license, and indicate if changes were made. 


\section{Appendix}

Table 3 Comparison of control and treatment groups: multi-nominal logistic regression with a social group (control group) as base outcome (log odds with standard errors in parenthesis, $\mathrm{N}=1399$ )

\begin{tabular}{lcccc}
\hline Variables & Radical Muslims & Muslim congregation & Right-wing extremist & Progress Party \\
\hline Constant & $.264(.335)$ & $.456(.324)$ & $-.039(.344)$ & $-.079(.355)$ \\
Female & $-.122(.173)$ & $-.165(.175)$ & $.309(.175)^{*}$ & $-.013(.173)$ \\
University & $-.125(.180)$ & $-.053(.184)$ & $-.311(.181)^{*}$ & $.119(.182)$ \\
Age 26-35 & $-.223(.400)$ & $-.597(.398)$ & $-.153(.412)$ & $-.528(.434)$ \\
Age 36-45 & $-.217(.399)$ & $-.151(.383)$ & $-.097(.408)$ & $.227(.407)$ \\
Age 46-55 & $-.117(.373)$ & $-.442(.367)$ & $-.019(.380)$ & $.072(.390)$ \\
Age 56-65 & $-.001(.370)$ & $-.298(.363)$ & $.289(.375)$ & $.163(.388)$ \\
Age 66-75 & $.044(.396)$ & $-.351(.394)$ & $.293(.402)$ & $.349(.410)$ \\
$75+$ & $.466(.596)$ & $.211(.597)$ & $.499(.614)$ & $.711(.607)$ \\
Progress Party & $.344(.290)$ & $.167(.303)$ & $.169(.304)$ & $.067(.308)$ \\
\hline
\end{tabular}

Reference categories: Male for female, 18-25 years of age for the seven age groups, lower education for the university degree dummy, and other party voters and non-voters for the Progress Party voter dummy

*Significant at the $10 \%$ level

\section{References}

Albertson, B., \& Gadarian, S. K. (2015). Anxious politics: Democratic citizenship in a threatening world. Cambridge: Cambridge University Press. https://doi.org/10.1017/CBO9781139963107.

Albertson, B., \& Gadarian, S. K. (2016). Did that scare you? Tips on creating emotion in experimental subjects. Political Analysis, 24(4), 485-491. https://doi.org/10.1093/pan/mpw022.

Altheide, D. L. (2006). Terrorism and the politics of fear. Cultural studies, critical methodologies, 6(4), 415-439. https://doi.org/10.1177/1532708616655749.

Bangstad, S. (2013). Eurabia comes to Norway. Islam and Christian-Muslim Relations, 24(3), 369-391.

Beetham, D. (1999). Democracy and human rights. Cambridge: Polity Press.

Berinsky AJ (2016) (Red.). New directions in public opinion. New York, NY: Routledge.

Berntzen, L. E., \& Sandberg, S. (2014). The collective nature of lone wolf terrorism: Anders Behring Breivik and the anti-Islamic social movement. Terrorism and Political Violence, 26(5), 759-779.

Bloch-Elkon, Y. (2011). The polls-trends: Public perceptions and the threat of international terrorism after 9/11. Public Opinion Quarterly, 75(2), 366-392. https://doi.org/10.1093/poq/nfr004.

Buzan, B., \& Wæver, O. (2003). Regions and powers. Cambridge: Cambridge University Press.

Cappelen, C., Kuhnle, S., \& Midtbø, T. (2016). Velferdssjåvinisme i Norge?_Et listeeksperiment. Norsk Statsvitenskapelig Tidsskrift, 31(02), 122-141. https://doi.org/10.18261/ issn.1504-2936-2016-02-02.

Chenoweth, E. (2013). Terrorism and democracy. Annual Review of Political Science, 16(1), 355-378. https://doi.org/10.1146/annurev-polisci-032211-221825.

Chong, D. (1993). How people think, reason, and feel about rights and liberties. American Journal of Political Science, 37(3), 867-899.

Christensen, D. A., \& Aars, J. (2017a). Does democracy decrease fear of terrorism? Terrorism and political violence. https://doi.org/10.1080/09546553.2017.1287700.

Christensen, D. A., \& Aars, J. (2017b). The 22 July terrorist attacks in Norway: Impact on public attitudes towards counterterrorist authorities. Scandinavian Political Studies, 40(3), 312-329. https:// doi.org/10.1111/1467-9477.12090.

Das, E., et al. (2009). How terrorism news reports increase prejudice against outgroups: A terror management account. Journal of Experimental Social Psychology, 45(3), 453-459. 
Davis, D. W., \& Silver, B. D. (2004). Civil liberties vs. security: Public opinion in the context of the terrorist attacks on America. American Journal of Political Science, 48(1), 28-46. https://doi.org/10.1 111/j.0092-5853.2004.00054.x.

Dragu, T., \& Polborn, M. (2014). The rule of law in the fight against terrorism. American Journal of Political Science, 58(2), 511-525. https://doi.org/10.1111/ajps.12061.

Druckman, J. N., \& Lupia, A. (2016). Preference change in competitive political environments. Annual Review of Political Science, 19(1), 13-31. https://doi.org/10.1146/annurev-polisci-020614-095051.

Engene, J. O. (2013). Mer overvåking, mer kontroll-Noen utviklingstrekk etter 22 juli. Tidsskrift for Samfunnsforskning, 54(02), 233-244.

Engene, J. O. (2016). Terrorism, counterterrorism, and democracy. In Y. Peters \& M. Tatham (Eds.), Democratic transformations in Europe: Challenges and opportunities (pp. 189-208). London: Routledge.

Epifanio, M. (2011). Legislative response to international terrorism. Journal of Peace Research, 48(3), 399-411. https://doi.org/10.1177/0022343311399130.

Europol. (2016). Changes in modus operandi of Islamic state terrorist attacks. Review held by experts from member states and Europol on 29 November and 1 December 2015. The Hague, 18th January.

Fimreite, A. L., et al. (2013). After Oslo and Utøya: A shift in the balance between security and liberty in Norway? Studies in Conflict and Terrorism, 36(10), 839-856. https://doi.org/10.1080/10576 10X.2013.823754.

Gadarian, S. K. (2010). The politics of threat: How terrorism news shapes foreign policy attitudes. Journal of Politics, 72(2), 469-483. https://doi.org/10.1017/S0022381609990910.

Gewirth, A. (1981). Are there any absolute rights? Philosophical Quarterly, 31(122), 1-16. https://doi. org/10.2307/2218674.

Hatemi, P. K., et al. (2013). Fear as a disposition and an emotional state: A genetic and environmental approach to out-group political preferences. American Journal of Political Science, 57(2), 279-293.

Huddy, L., \& Feldman, S. (2011). Americans respond politically to 9/11: Understanding the impact of the terrorist attacks and their aftermath. American Psychologist, 66(6), 455-467. https://doi. org/10.1037/a0024894.

Huddy, L., et al. (2002). The consequences of terrorism: Disentangling the effects of personal and national threat. Political Psychology, 23(3), 485-509. https://doi.org/10.1111/0162-895X.00295.

Huddy, L., et al. (2005). Threat, anxiety, and support of antiterrorism policies. American Journal of Political Science, 49(3), 593-608. https://doi.org/10.1111/j.1540-5907.2005.00144.x.

Husabø, E. J. (2013). Counterterrorism and the expansion of proactive police powers in the Nordic states. Journal of Scandinavian Studies in Criminology and Crime Prevention, 14(1), 3-23. https://doi. org/10.1080/14043858.2013.773759.

Inglehart, R., \& Norris, P. (2016). Trump, Brexit, and the rise of populism: Economic have-nots and cultural backlash. HKS Working Paper No. RWP16-026. Retrieved from https://papers.ssrn.com/sol3/ papers.cfm?abstract_id=2818659\#\#.

Jakobsson, N., \& Blom, S. (2014). Did the 2011 terror attacks in Norway change citizens' attitudes toward immigrants? International Journal of Public Opinion Research, 26(4), 475-486. https://doi. org/10.1093/ijpor/edt036.

Klar, S. (2013). The influence of competing identity primes on political preferences. Journal of Politics, 75(4), 1108-1124. https://doi.org/10.1017/S0022381613000698.

Lehrke, J. P., \& Schomaker, R. (2014). Mechanisms of convergence in domestic counterterrorism regulations: American influence, domestic needs, and international networks. Studies in Conflict and Terrorism, 37(8), 689-712. https://doi.org/10.1080/1057610X.2014.921769.

Lerner, J. S., et al. (2003). Effects of fear and anger on perceived risks of terrorism: A national field experiment. Psychological Science, 14(2), 144-150. https://doi.org/10.1111/1467-9280.01433.

Midtbøen, A. H., \& Steen-Johnsen, K. (2016). Ytringsfrihetens grenser i det flerkulturelle Norge. Nytt Norsk Tidsskrift, 32(01-02), 21-33.

Mitchell, M. N. (2012). Interpreting and visualizing regression models using Stata (Vol. 5). College Station, TX: Stata Press.

Moe, V., et al. (2016). Hvis de hadde oppført seg som vanlige nordmenn, hadde alt vært greit, tror jegNordmenns syn på årsaken til negative holdninger til jøder og muslimer. FLEKS-Scandinavian Journal of Intercultural Theory and Practice, 3(1), 1-17. https://doi.org/10.7577/fleks.1685.

Mudde, C. (2016). The study of populist radical right parties: Towards a fourth wave. C-REX Working Paper Series, No. 1, 2016. Oslo: C-REX-Center for Research on Extremism. 
Mueller, J., \& Stewart, M. G. (2012). The terrorism delusion: America's overwrought response to September 11. International Security, 37(1), 81-110. https://doi.org/10.1162/ISEC_a_00089.

Mutz, D. C. (2011). Population-based survey experiments. Princeton: Princeton University Press.

Nesser, P. (2014). Toward an increasingly heterogeneous threat: A chronology of jihadist terrorism in Europe 2008-2013. Studies in Conflict and Terrorism, 37(5), 440-456. https://doi. org/10.1080/1057610X.2014.893405.

Nesser, P., Stenersen, A., \& Oftedal, E. (2016). Jihadi terrorism in Europe: The IS-effect. Perspectives on Terrorism, 10(6), 3-23.

Neumayer, E., Plümper, T., \& Epifanio, M. (2014). The "peer-effect" in counterterrorist policies. International Organization, 68(01), 211-234. https://doi.org/10.1017/S0020818313000362.

Nordenhaug, I., \& Engene, J. O. (2008). Norge i kamp mot terrorisme. Oslo: Universitetsforlaget.

Ogan, C., et al. (2014). The rise of anti-Muslim prejudice. International Communication Gazette, 76(1), 27-46. https://doi.org/10.1177/1748048513504048.

Pantazis, C., \& Pemberton, S. (2009). Policy transfer and the UK's 'war on terror': A political economy approach. Policy and Politics, 37(3), 363-387. https://doi.org/10.1332/030557309X462529.

Petersen, M., et al. (2011). Freedom for all? The strength and limits of political tolerance. British Journal of Political Science, 41(03), 581-597. https://doi.org/10.1017/S0007123410000451.

Pokalova, E. (2015). Legislative responses to terrorism: What drives states to adopt new counterterrorism legislation? Terrorism and Political Violence, 27(3), 474-496. https://doi.org/10.1080/09546 553.2013.809339.

Politiets Sikkerhetstjeneste (PST). (2016). Trusselvurdering 2016. Oslo.

Rosenfeld, B., Imai, K., \& Shapiro, J. N. (2016). An empirical validation study of popular survey methodologies for sensitive questions. American Journal of Political Science, 60(3), 783-802. https://doi. org/10.1111/ajps.12205.

Roth, K. (2016). Twin threats: How the politics of fear and the crushing of civil society imperil global rights. Human Rights Watch, World Report 2016 (pp. 1-20). New York: Human Rights Watch.

Savelkoul, M., et al. (2012). Comparing levels of anti-Muslim attitudes across Western countries. Quality \& Quantity, 46(5), 1617-1624. https://doi.org/10.1007/s11135-011-9470-9.

Skjervheim, Ø., \& Høgestø1, A. (2015). Norwegian citizen panel 2015, fifth wave. Methodology report. Bergen: Norsk medborgerpanel/Ideas2evidence.

Sniderman, P. M., Petersen, M. B., Slothuus, R., Stubager, R., \& Petrov, P. (2019). Reactions to terror attacks: A Heuristic model. Political Psychology, 40, 245-258.

Sniderman, P. M., et al. (2014). Paradoxes of Liberal democracy: Islam, Western Europe, and the Danish cartoon crisis. Princeton: Princeton University Press.

Steen-Johnsen, K., Fladmoe, A., \& Midtbøen, A. (2016). Ytringsfrihetens grenser. Sosiale normer og politisk toleranse. Rapport. Oslo: Institutt for samfunnsforskning.

Strabac, Z., \& Listhaug, O. (2008). Anti-Muslim prejudice in Europe: A multilevel analysis of survey data from 30 countries. Social Science Research, 37(1), 268-286. https://doi.org/10.1016/j.ssres earch.2007.02.004.

Sunstein, C. R. (2004). Fear and liberty. Social Research, 71(4), 967-996.

Tilley, J., \& Hobolt, S. B. (2011). Is the government to blame? An experimental test of how partisanship shapes perceptions of performance and responsibility. Journal of Politics, 73(2), 316-330. https:// doi.org/10.1017/s0022381611000168.

Wilkinson, P. (1992). International terrorism: New risks to world order. In I. J. Baylis \& N. Rengger (Eds.), Dilemmas of World Politics: International Issues in a Changing World (pp. 228-257). London: Clarenden Press.

Wollebæk, D., Enjolras, B., Steen-Johnsen, K., \& Ødegård, G. (2012). After Utøya: How a high-trust society reacts to terror-trust and civic engagement in the aftermath of July 22. PS: Political Science \& Politics, 45(1), 32-37. https://doi.org/10.1017/s1049096511001806.

Zavala, D., et al. (2010). Political conservatism, need for cognitive closure, and intergroup hostility. Political Psychology, 31(4), 521-541.

Publisher's Note Springer Nature remains neutral with regard to jurisdictional claims in published maps and institutional affiliations. 